\title{
Age-related decrease in physical activity and functional fitness among elderly men and women [Corrigendum]
}

Milanović Z, Pantelić S, Trajković N, et al. Clin Interv Aging. 2013;8:549-556.

On page 551, Table 1, the Note should have read:

Notes: ${ }^{*} P<0.05$. Descriptive parameters for women reproduced from Facta Universitatis

Series: Physical Education and Sport, Vol. 10, No 4, Special Issue, 2012, 289-296.

\section{Publish your work in this journal}

Clinical Interventions in Aging is an international, peer-reviewed journal focusing on evidence-based reports on the value or lack thereof of treatments intended to prevent or delay the onset of maladaptive correlates of aging in human beings. This journal is indexed on PubMed Central, MedLine,
CAS, Scopus and the Elsevier Bibliographic databases. The manuscript management system is completely online and includes a very quick and fair peer-review system, which is all easy to use. Visit http://www.dovepress. com/testimonials.php to read real quotes from published authors. 